CSÁKÓ Zsófia ', NYIRI Zoltán ', SZABADOS Máté 1,2, ERDÉLYI Norbert 1,2, BALOGH Boglárka Sára 1,2, KAKUCS Réka ', SZIGETI Tamás '

'Nemzeti Népegészségügyi Központ, Budapest; ${ }^{2} E L T E$ Környezettudományi Doktori Iskola, Budapest

E-mail: csako.zsofia@nnk.gov.hu

DOI: https://doi.org/10.29179/EgTud.2021.3.32

\title{
Levoglükozán a vizeletben: a fatüzelés egy lehetséges biomarkerének nyomában
}

\section{Összefoglalás:}

Hazánkban a lakossági tüzelés, ezen belül is a biomassza és a háztartási hulladék égetése felelős a fütési szezonra gyakran jellemző, kedvezőtlen levegőminőségért. A levoglükozán a fatüzelés egyik leggyakrabban alkalmazott marker vegyülete, azonban biomarkerként történő alkalmazásáról az eddigi kutatások ellentmondó eredményekről számoltak be.

A Nemzeti Népegészségügyi Központ egy felmérést indított, hogy vizsgáljuk a lakossági tüzelés levegőminőségre gyakorolt hatását és megbizonyosodjunk arról, hogy a levoglükozán, mint biomarker alkalmazható-e a fatüzelésből származó légszennyezettség jelzésére. Ennek keretében két, különböző fütési szokásokkal rendelkező magyarországi település (Nógrádmegyer és Esztergom) levegőminőségét vizsgáltuk fútési és nem fútési szezonban két-két héten keresztül. A mintavételi kampány során a PM ${ }_{2.5}$ méretfrakció gyűjtése minden nap 18:00 órától másnap 18:00 óráig tartott. A humán biomonitoring vizsgálatokhoz a reggeli első vizeletmintákat gyűjtöttük a kampány különböző napjain. A PM ${ }_{2.5}$ minták levoglükozán-tartalmának mérését GC-MS módszerrel végeztük, míg vizelet esetében a komplex mátrix miatt egy többlépcsős minta-előkészítési eljárást dolgoztunk ki a zavaró komponensek eltávolítására, a célkomponens meghatározására pedig GC-MS/MS módszert használtunk.

A $\mathrm{PM}_{2.5}$ mintákban a levoglükozán medián koncentrációja a fútési időszakban egy nagyságrenddel magasabb volt, mint a nem fútési időszakban. A vizeletben mért értékeket összehasonlítva nagyságrendbeli eltérést nem tapasztaltunk a medián értékek között. A vizeletminták levoglükozán koncentrációjának elemzése során szignifikáns eltérés csak a felnőttek esetén volt kimutatható a fütési és nem fútési szezon között Nógrádmegyeren, illetve a fütési szezonban a két település között. Mindkét mintavételi időszakban a levoglükozán koncentrációja jelentősen magasabb volt a gyermekek vizeletében, mint a felnőtt résztvevők mintájában. A PM ${ }_{2.5}$ mintákban és azok mintavétele során gyüjtött vizeletmintákban mért levoglükozán koncentrációk között nem volt szignifikáns összefüggés, kivéve Nógrádmegyeren a felnőttek esetén a két mintavételi időszakot együttesen elemezve.

Az eredmények alapján a levoglükozán nem alkalmas a biomassza tüzeléséből származó légszennyezettség biomarkereként, mivel a levegő levoglükozán koncentrációja mellett a vizeletben mért koncentrációját valószínúleg jelentősebben befolyásolják egyéb tényezők.

Kulcsszavak: biomarker, lakossági szilárd tüzelés, levoglükozán, légszennyezés, vizelet 